\title{
Culture \& Education: An Analysis on Schooling of an Ethnic Minority Village in Pre-modernization
}

\author{
Xiaoyan Wang \\ Key Research Institute of Humanities and Social Sciences at University \\ Center for Studies of Education and Psychology of Ethnic Minorities in Southwest China \\ Southwest University, Chongqing 400715, China \\ E-mail: tq06na0@163.com
}

Received: March 25, 2011 Accepted: May 3, 2011 doi:10.5539/ass.v7n8p59

The study is supported by the Fund of Humanities Social Sciences of Ministry of Education. General Research Project. Study on Obstacle Factors of elementary education of Western China (2009): An Empirical Study of Cultural Patterns \& Unofficial Institutions. [09YJAZH079\#]

\begin{abstract}
The study focuses on a Miao village of Southwest China, where the educations both home and community existing in the village are affecting the children. Before the place becomes part of modern society, traditional culture working in their reality life as well as rooting deeply in villagers' mind. They haven't recognized the meaning of the schooling education completely yet. The study finds that the point is that there are the different education types between schooling and home \& community, including different contents, methods and aims of teaching. The findings suggest that they are badly in need a process of getting themselves to adapt to schooling, that is not the time problem, but understanding that "why I am going to school", and "what I am studying for".
\end{abstract}

Keywords: Miao people schooling, Values, Cultural tradition

\section{Introduction}

The central government has attached importance to the education of every grade, especially elementary education of minority ethnic groups who are living in remote rural areas. In the past decades the Chinese educational system has covered all of minorities' areas, and all boys and girls have access to school to receive 9-year-long compulsory education. There is no doubt on the enrollment of all school-age children. However, the achievement of students' learning is be worried as it be in low level in some places in which traditional culture is still playing an important role. The paper takes B village, located west Congjiang County, Miao \& Dong minority autonomous prefecture of Southeast Guizhou prov., Southwest China, where the consuetudinary rules, primitive believes and traditional lifestyles have been kept in an existing state, as a case of observation and research, because of the low achievement of schooling there. There are 478 households, total 2250 people who are all Miao minority people, but few have received college educations. For the sake of geographic isolation and difficulty in traffic in the past years, as well as the limitation of language and marriage circles, they seldom if ever contacted outside the village. Although B village has opened to the tourist as the first batch traveling villages of Guizhou Province since 1999, and Miao traditional culture of the village has undergone major transformations during the last decades, it has been longstanding traditional extension deeply in the village, if you step into the village, you can see indigo planted in front of rooms or in vacancy lands, women weaves, embroiders, wax print and dye clothes with indigo leaves, hear rhythm ding-dong sound which women beat the cloth with wooden hammer every corner of the village. The traditional culture, including primitive religion and custom, such as "Tree worship", "Tree burial" (use a tree trunk as a coffin), village marriage circles, and festival days are still preservation. Unique hair style and clothes show traditional life and culture of them. Due to all of characters of material culture and psychical culture from the village of the Miao, in this paper, the place is named a "pre-modernization" where life educations which lie on its traditional culture, the home education and the community education have been playing a very important role.

Much has been written on ethnic groups' gap in achievement already. Teng xing points out that the different 
schooling achievement is due to different language, family income, traffic condition and population quality, etc. (Teng Xing, Yang Hong: 2004). Hong Yanbi says: the main factors which affect ethnic minorities' educational attainment are urban-rural geographical disparities, occupational structures (classes), cultural differences, and political processes (Hong Yanbi: 2006). The overseas researchers think that the discrepancy has some certain relations with the discrepancy of races, incomes and genders (Gamoran, 2001. Hallinan, 2001. Hedges \& Nowell, 1999), and some of them think with the educational levels of parents and incomes of families (Hofferth, Boisjoly \& Duncan, 1998, Karen, 2002). The findings of educational anthropology show that there is a closing relationship between the culture and the education. On one hand, if there is no education, any culture couldn't be passed down or be continued, on the other hand, culture is always affecting education, no matter what phases of culture goes in, in advanced or not. To some extent, cultural traditions restrict educational activities that different cultural tradition will make different achievement of students' study and recognizing of schooling. This paper presents the reason of educational behindhand, and explores the relationships between schooling and cultural tradition as well as between educational needs and social reality.

\section{Education types}

\subsection{Schooling}

Every school-age child from the village goes to the elementary school of the B village that was rebuilt in 2002 as a "hope school" project. There are 286 pupils making up enrollment rate of $95 \%$ of school-age child. As a result of conservative conception, in the past, no girl goes to school rather than at home helping parent herd buffaloes or raising ducks, and then gets married at 16-age or so. After the 90s, this kind of situation already has changed. The parent has to send kids to go to school due to the Compulsory Education. With the "free two and allowance one" policy carried out, home financial burden of children schooling has already greatly reduced down. The parent of the elementary pupil's hands over 10yuan per semester only for buying the exercise books, pencils and so on. The students in Boarding school of Congjiang County are provided the food allowance. It is seem that any dropout of financial cause has disappeared. However, some problems are still there. We cite the problems of the B village elementary school as the follows:

\subsubsection{Difficult in teaching and studying}

There are 7 classes, about 40 students in each, 7 teachers totally, only one of them using bilingual languages both Miao and mandarin in teaching. Due to no preschool in the village, children cannot speak Han Chinese when they enter the school, where the national universal textbooks written in Han Chinese are used in teaching. In the shortage of bilingual teachers, the teaching-material with long text content is too difficult to learn to the first and second grade students who cannot understand Han Chinese. While writing characters is a tough work to pupils at the age of 7 8 of Miao at the beginning, teachers must catch up with the teaching schedule in order to finish their teaching tasks. So students feel like "take plane", and very hard to follow the course progress, then most of them lost their interested in the study. As the result, majority students have got low test results. Average 5 6 of them every year can able to pass the high school entrance examination. From 1949 until now, only two graduates were from the teacher education schools.

\subsection{2 "Reading uselessness"}

In recent years, after finished high-school education, some of students wouldn't like to go out for working or to help parents in the fields, rather than stay at home and live on parents. Some of them are hired out for working, but come back home soon causing of unstable works and limited incomes. As the information on that it is hard to find suitable jobs for graduates made parents of the village generally appearing viewpoint of misunderstanding on schooling, i.e. "working later is inferior to early" and "reading uselessness". So parents didn't pay attention to child's study seriously, never asked them to finish homework, never bought a book for them, but always asked them (normally teenagers) to do some housework, even farm works when it is schooling time. Therefore the 9-year-long compulsory education is being ignored by parents, needless to say to support kids to get more education after the compulsory schooling.

\subsubsection{The mainstream culture replaces traditional one of minority people}

Schooling' aim is to bring up successors of a new generation who meet the needs of modern civilization. What the schooling transmits is the mainstream culture which brings knowledge, values and regulations. Comparing with majority people, schooling means new culture from the outside society for Miao minority people. Through 9-year-schooling, they would find themselves abandoning most of their own culture including some outmoded rules or old custom, being in admiration or advocacy of the mainstream culture, as well as using Han Chinese language easily. 


\subsection{Life-education}

Before the regular schools' establishment, children were educated in the course of life at home where they were instructed to do something or were told what should do or not do by parent. They always took part in the all kinds of community's activities with parent. Here we name this kind of educations as life-education in the paper. The life-education isn't replaceable one, even though there is schooling, for which exists all the time in the life of people from birth to death. Just like Furth said, the most valuable function of parent is to give children their community's massive traditional culture by demonstration and educational instruction, no matter the nursery or the fine school, cannot replace the family completely in this function(Furth:2002:83). The life-education is from life practice of the villagers in their housework, farm-work, festival holidays activities, custom, religion and life-style. All of life-practices what children take part in turn into the educational elements, cultivates children growing up. More exactly, all members including adults in all ages have being developing by the life-education. In a word, life-education is a kind of plain one which makes education root in the reality life, which shapes people as the village members.

\subsubsection{House works education}

In B village, normally there is different works for husband and wife. Husband always does some farm works, while wife often remains at home doing something like mothering, feeding pigs, washing, cooking, weaving, dyeing, etc.. People used to the gender arrange of the jobs in family. Parent teaches boys everything in order to helping them dealing with their own life in the future, such as how to farm, herd buffalo, raise ducks, build or repair the house and granary, to knit bamboo basket, etc.. When kids up to 6 7 years old begin to be taught to do needlework for girls, to play dances and the Lusheng which is a pipe musical instrument for boys. Teenagers must go pass the "adult ritual", which boy shows "catching fish" in the river, girl manages "the line-up yarn", a kind of needle work which is harder than spinning yarn, thump clothe and dye, etc.. The ceremony of "adult ritual" is sort of a big presentation about life technique of kids learned already to all relatives and villagers who come saying congratulations. And this ceremony confirms that he or she has become an adult and be in the right social position.

\subsubsection{The moral education}

The moral education is mainly taught by parent during children's growing. When child raise buffalo on hill, he always is warned that don't damage crops of neighbors, don't steal things from neighbor's fields. Parent always says that if you did something bad, you will be buried alive. The bad behaviors of stealing as well as destruction which harm for private possession or marriage would be punished strictly. The measure of punishment was included in old custom rules of the village. Theft behavior was guilty of the most heinous crimes for which even live buried decades ago. Now people in charge of theft submit both liquor and meat of each 60 kilogram to divide in pieces to all villagers instead. But traditional rules deeply are remained in villagers' memory, and they often use them to frighten their disobedient child. So villagers said there is no stealing behavior happened in their village at all. Although the punishment of burying alive had been instead of liquor and meat, many rules of village's custom actually have been kept up, and still work in villagers' daily life. The rules which were passed down by oral way in the past are written down, that still play an important role in the moral fields of villagers.

\subsubsection{The sexual education of puberty}

There are several holidays for love days. For instance, swing festival, lunar New Year's Day (from $1^{\text {st }}$ to $13^{\text {th }}$ at the first month in new years), December festival (from $1^{\text {st }}$ to ninth) which traditional love holidays provide convenience for young people meeting mates. They learn the elementary knowledge of puberty physiology education and related knowledge of sex during the love days. The actions and games provide "live textbooks" of sex education. If young people find the right one who falls in love will marry him/her.

\subsubsection{The value views' educations in believes}

Primitive faith still exists in the village. According to certain needs of people, they often choose god-trees to worship. In the village, some big trees were named god trees of worshiping, such as "Eliminating calamities tree", "evergreen trees" and so on. They often choose the fragrant camphor tree and Chinese sweet-gum generally as the worship's objects trees. If somebody will leave far away from home or somewhat unfortunate matter has happened already in the family, they would impetrate the Eliminating calamities tree for family's safety. When child is being sickly, not strong, parent must visit a sorcerer to ask looking for a god tree to pray for the child. The sorcerer often chooses a tree with luxuriant leaves never fall. Because they think that if the tree thrives, and with evergreen leaves meaning that the child will grow up well. When it is a holiday, parent always takes the child with some wine and meat (sometimes salted fish instead) to worship the tree. Worshiping the sun 
is also the same as other gods. Some villagers need to worship the sun god, others tree gods. To a certain extent, those primitive believes (trees, the sun) would help for villagers creating the self-awareness, the group consciousness or the social sentiment. Emile Durkheim pointed out that any religious both appearances \& existences are helpful rather than meaningless for human society inevitably. Meanwhile it would be good for people to creating world view, value view, and consciousness of balancing both nature and humanity.

\subsubsection{The education of collective spirit}

Limited by the geography relations, as a community unit, villagers need to develop a group consciousness or a common social sentiment in order to realize mutual unity and consistent. It is very important for the collective stabilization in long time that the villagers keep with a common social sentiment. Meetings in all kinds of community activities, such as weddings or funerals, "adult rituals" or festival holidays provide chances for people to exchange their thoughts and knowledges of daily life each other. There is a special gathering, named "the Carry Firewood's Gathering", which is sort of way to improve emotion among community people. Every year sworn brothers hold a gathering in the host house where calls for firewood carried. At that day, all sworn brothers come to give a hand for carrying firewood, while the housewife prepare a feast for coming brothers and their wives. They sit around eating, talking, laughing and playing porker until midnight. The gathering makes both cooperation among sworn brothers and progression emotion each other.

When people gathered, they understood and communicated mutually to strengthen their common society sentiment unceasingly. The influence of meetings on people brings them a common society sentiment which detail in unification moral, united as one, and so on. Under the influence of the unification moral, children know what collective spirit is and understand that members of the village should stick togather.

Since childhood, B village people have learnt all kinds of life and entertainment's ways from parents. They also gain practices of religion, weddings, funerals, and so on which everything has took place in the village over years. They grow up in the life-education. And in the future they will teach their children the life style and survival knowledges just like their parents did.

\section{Analysis and viewpoint}

Obviously, Miao students and parents have a negative manner to the current education. Is this the result that they want to protect own culture from assimilation of the mainstream culture? The answer is "not" definitely. On one hand, they are now being affected by many unofficial institutions including in their traditional culture, on the other hand there is no link directly between their demand of reality life and the aim of current school education. They grow up under influencing of traditional culture including social rules, values, cooperation and solidarity, morality, etc. which shaped their basic personality already. When they come into elementary schools they find the educational type totally different from their life-education, then they try to make themselves to meet with the new one. The life educations foster children adaption to native village life, the school education to modern city life which is far from their reality life. When the villagers have got steady grain crop every year, which bring them enough food and clothing, they don't like undergo unpredictable life outside the village. They also cannot stand to let the children go out for work to survive in a complicated and strange world that it is possible bring them be in a terrible survival crisis. The story of some people who stayed outside the village for working but came back soon, reflects that they do not adapt to the competition of city life, especially, suffer from the cultural shock. There is stable life in the village for them, and they also familiarise the village life, after all. Because there is enough land to support them and their children's life currently. In parents' eyes, the children's future has been designed. They will live as the same as their parents, and their today's life will be future of the children.

In this circumstance, they think that what all knowledge learned from school is uselessness for living in the village. This is one of the reasons that they couldn't make progress in achievement, and behind the teaching schedule. Just like Fei Xiao-tong said that it needn't use Chinese character in the folk society before rural society's essence has changed. (Fei Xiaotong: 1998:23) A villager I met who received elementary school when he was young said that he is satisfied with his nowadays life because his family has got enough rice and vegetables from planting the fields. Except part of food for the family using, the left can be sold for making money. He expects his children will live as the same as his. He thinks that it is enough that after children finishing the elementary schooling, they can be able to read, write and count, then they can read the instruction booklet of the pesticide and chemical fertilizer, count money of family's income and expenditure. Unfortunately, this kind of view is rather popular in the village. Most of parents don't want to spend much more money for children's senior high schooling. In the process of education, if student individual does not demand school education, the education will lost its function and dynamic. In a word, the school education has still not been regarded as one of method for make a living for child's future in the village. Parent has not seen what benefited 
from the school education they have got yet.

However, we find that the cadres and the teachers of the village expect their own children to be able to go to college in the future, and set money aside for children's higher education. The people, who have experiences of working outside the village, think that the school education is good for children. They express their view on the school education that the more education children received, the better life they would have.

\section{Conclusions}

Education always is as a survive way for human being inevitably. When the village has not become part of modern society yet, life-education has still occupied significant position in their life. Although they are being affected by the external person unceasingly, in villager's view, it is not necessity to receive much more school education, and the school education is not necessary socialized method for the community members.

As a main transmit path of the mainstream culture, schooling has been encountering a difficult time before minorities themselves have changed their inherent cultural psychology, value and the behavior manner, which is different from the mainstream culture. The school students have to deal with the two educational types including different contents, methods and aims of teaching. The findings suggest that a suitable environment or process of getting them to adapt to school education is needed, that it is not the time problem, but making sure that "why I am going to school", or "what I am studying for".

The more they have experiences of staying outside the village, the better they will recognize the meaning of schooling. Along with the development of tourism economic and its contacting with the outside, the education will become necessary demand indispensably for them. We believe that villagers will understand the meaning of schooling in the near future.

\section{References}

Benedict Ruth. (1989). Patterns of Culture. Houghton Mifflin Company.

Emile Durkheim. (1999). The Elementary Forms of the Religious Life, Chinese Version. Beijing: Minzu University of China Press. charpter7, pp. 224-263.

Fei, Xiaotong. (1998). Local China. Beijing: Beijing University Press, pp.19.

Gamoran, A. (2001). American Schooling and Educational Inequality: A Forecast for the $21^{\text {st }}$ Century. Sociology of Education, 74(extra Issue), pp. 135-153.

Hallinan, M T. (2001). Sociological Perspectives on Black-White Inequalities in American Schooling. Sociology of Education, 74(2), pp. 112-137.

Hedges L.V. \& A. Nowell. (1999). Changes in the Black-White gap in achievement test scores. Sociology of Education, 72(2), pp. 111-135.

Hong, Yanbi. (2010). Ethnic Groups and Educational Inequalities: An Empirical Study of the Educational Attainment of the Ethnic Minorities in Western China. Chinese Journal of Sociology, (02). [Online] Available: http://epub.cnki.net/grid2008/detail.aspx?filename=SHEH201002004\&dbname=CJFD2010

International Social Science Series. (2000). Social Transformations: Multicultural and Multiethnic Societies. Beijing: Social Science Academic Documentation Publishing House, pp. 46-85.

Joseph Zajda, Karen Biraimah, \& William Gaudelli. (2008). Education and Social Inequality in the Global Culture, Globlisation, Comparative Education and Policy Research, Vol. 1, Chapter 10. pp. 155-180. doi:10.1007/978-1-4020-6927-7, http://dx.doi.org/10.1007/978-1-4020-6927-7

O'Connor, C. (1999). Race, Class, and Gender in America: Narratives of Opportunity among Low-Income African American Youths. Sociology of Education, 72(3), pp. 137-157.

Qian Minhui. (2007). Discontinuity and Reconstruction: Hidden Curriculum in School Education in Ethnic Minority Regions. Northwest Ethno-National Studies, 52(1), pp. 58-68. [Online] Available: http://dlib.edu.cnki.net/kns50/detail.aspx?dbname=CJFD2007\&filename=SAGA200701009.

Raymond Firth. (2002). Human Types. Fei Xiaotong (Translator), Chinese Version. Beijing: Hua xia Press, chapter 4, pp. 76-101, chapter 6, pp. 121-148.

Spindler. G. D. (1974). Education and Cultural Process: Toward Anthropology of Education. New York: Holt, Rinehart \& Winston.

Teng, Xing \& Yang, Hong. (2004). A Native Interpretation of Attribution Theory of the West in Discussing Low Academic Achievement: An Anthropological Field Work of the Education of the Education of the Lahu 
Nationality in Mountain Area. Journal of Guangxi University for Nationalities (Philosophy and Social Science Edition), 26(3), pp. 2-17. [Online] Available: http://dlib.edu.cnki.net/kns50/detail.aspx?dbname=CJFD2004\&filename $=$ GXZS200403002

Wan, Guofang. (2008). The Education of Diverse Student Populations: A Global Perspective. Explorations of Educational Purpose, Volume 2. Chapter 1. pp. 7-28. doi:10.1007/978-1-4020-8204-7, http://dx.doi.org/10.1007/978-1-4020-8204-7

Zhang, Xiaosong. (2004). Miao People of the Mountains. Cultural Geography, Vol. 04, pp. 100-112. [Online] Available: http://211.83.206.51/kns50/detail.aspx?QueryID=61\&CurRec=1

Zheng, Jinzhou. (1996). Culture and Education: A Discuss on the Relationship between the Both. Journal of ShangRao Teachers College, Vol. 1, pp. 1-5. [Online] Available: http://dlib.edu.cnki.net/kns50/detail.aspx?dbname=CJFD1996\&filename=SRSX601.000 